\begin{tabular}{|l|l|l|l|l}
\hline Z. Geomorph. N.F. & Suppl.-Bd. 99 & $75-89$ & Berlin·Stuttgart & September 1995 \\
\hline
\end{tabular}

\title{
Microfabrics, grain-size-distributions and grain surface textures in Late Pleistocene basin sediments of Brandenburg (Northern Barnim)
}

\author{
by
}

LUTZ SCHIRRMEISTER, Berlin

with 4 photos, 6 figures and 1 table

\begin{abstract}
Summary. The Biesenthal Basin formed by thawing of dead ice, is located at the northern rim of the Bamim Plateau north of Berlin; in it sedimentary processes varied considerably during the Late Weichsel Glacial Period. Their variations are reflected in sedimentary fabrics, grain size distributions and repeated overprinting of surface textures on quartz grains. The glacifluviolimnic, limnic and aeolian sediments were deposited on the shore of a periglacial water within the area shaped by the last glacial advance; presently it is located at the border between lowlands and plateau. The sedimentary sequence is characterized by variations and deformations at the scale of micrometers, hence the present study focussed on microfabric analysis.
\end{abstract}

Zusammenfassung. Das Sedimentationsgeschehen am Rand eines durch Toteisaustau entstandenen Beckens (Biesenthaler Becken) am N-Rand der Barnimhochfläche nördlich von Berlin ist im Weichselspätglazial durch einen intensiven Wechsel gekennzeichnet. Dieses wird durch Analysen von Sedimentgefügen an Dünnschliffen, sehr stark schwankende Korngrößenparameter und die mehrfache Überprägung von Oberflächenstrukturen auf Quarzkörnern belegt. Die glazi-fluviolimnischen, limnischen und äolischen Sedimente im Uferbereich eines periglaziären Gewässers im Brandenburger Jungmoränenland bauen im heutigen Grenzbereich zwischen Becken und Hochfläche eine bis in den $\mu \mathrm{m}$-Bereich gestörte und wechselnde Folge auf, die vor allem auf ihr Mikrogefüge hin untersucht wurde.

Résumé. Le processus de sédimentation en bordure du Bassin de Biesenthal se caractérise par des changements intenses. Ce Bassin de Biesenthal, lui-même formé à la suite du dégel de glace morte durant la période "Weichsel" glaciaire finale, est situé sur la partie Nord du Plateau de Barnim, au Nord de Berlin. L'hypothèse des changements intenses est fondée sur des analyses de sédiments préparés en lames minces. On observe différentes grosseurs de grain et multiples structures superficielles sur les grains de quartz, dues à des pressions. Les sédiments glaci-fluviaux, glaci-lacustres, limniques et éoliens, dans les zones d'eaux périglaciaires de la région morainique jeune du Brandebourg, ont formé des couches disloquées et alternées d' épaisseur allant jusqu'au micron. Ces couches sont étudiées ici, en particulier dans leurs structures microscopique.

Introduction

The objects of this research are Late Glacial sediments at the northeastern margin of the Biesenthal Basin (Northern Barnim) north of Berlin formed by thawing of dead ice (Fig. 1). The main emphasis of investigation is on sedimentary microfabrics, granulometric analysis and the surfaces of quartz grains. The results are interpreted in terms of sedimentary processes and of basin formation related to thawing of dead ice. The investigations were supported by the German Research Foundation (DFG) and constitute a follow-up study on results presented by NITZ (1984), CHROBOK et al. (1986) and CHROBOK \& NITZ $(1987,1989)$. 


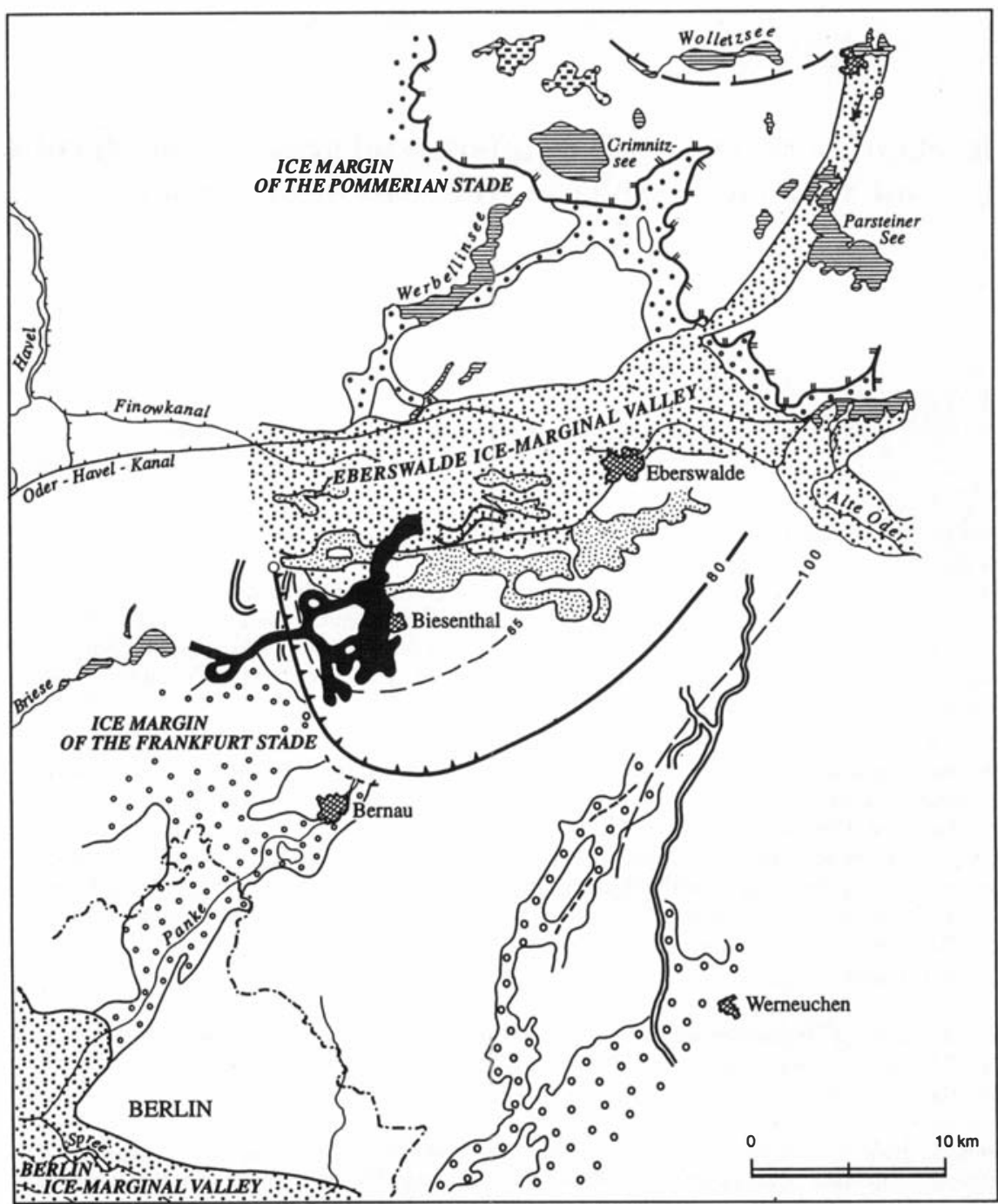

Fig. 1. Location of the area of investigation "Biesenthal Basin": The Biesenthal Basin is situated behind the Frankfurt ice margin which is considered part of the Brandenburg stade (Weichsel stage). It was formed at the northern part of the Barnim till plateau and within the upper terrace of the Eberswalde ice marginal valley.

\section{Sedimentary fabrics}

\subsection{Succession of sediments in profiles}

The Late Glacial sedimentary complex of the eastern basin margin consists of glacifluviolimnic fine gravels to medium grained sands, a finely laminated fine sand-silt-sequence and a silty fossil bearing horizon of lacustrine lime sand (Fig. 2). This upper horizon mostly has been partially eroded; at the top sedimentary structures were obliterated by pedogenesis. It is overlain by relatively thick colluvium or, else, above an unconformity capped by an aeolian sand sheet. 


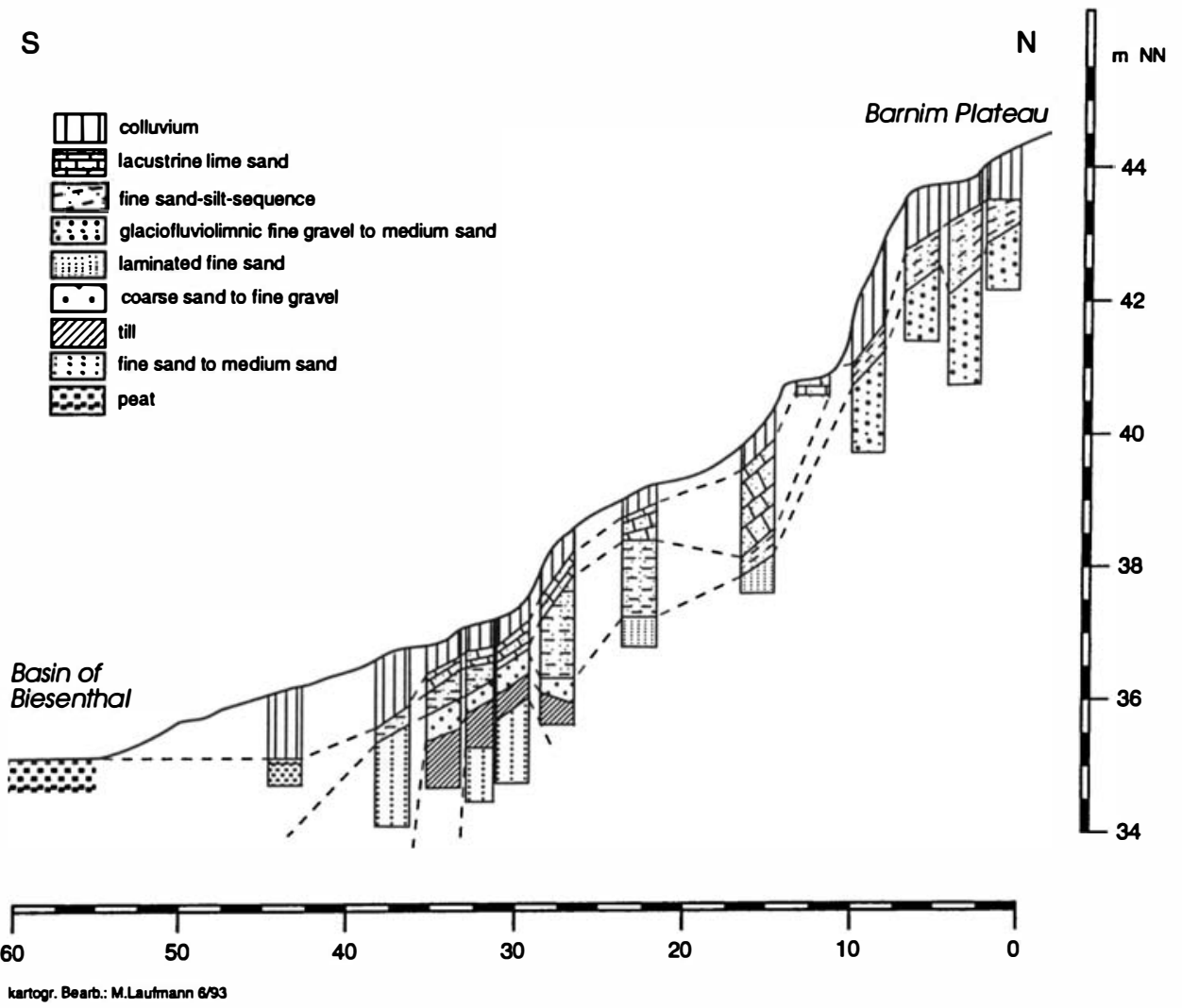

Fig. 2. Cross profile through the eastern margin of the Biesenthal Basin shows the association of various basin sediment types.

The glaciofluviolimnic basin sediments consist of laminated fine to medium sand (fs-ms) alternating with $5-10 \mathrm{~cm}$ thick layers of coarse grained sand which dip $25-30^{\circ}$ E-ENE. The overlying sequence consists of alternating layers of fine sand, $4-5 \mathrm{~cm}$ thick, and silt, $1-2 \mathrm{~cm}$ thick. Closely spaced normal faults dipping steeply $\mathrm{W}$ found within this sequence are attributed to thawing of dead ice. The fine sand-silt-sequence is poor in carbonate and lacks fossils; it is covered by a lag deposit of pebbles shaped by wind which in turn is overlain by a silty, carbonate-rich, laminated layer of lacustrine lime sand. This layer has been faulted less than the sediments below.

\subsection{Microfabrics}

To study microfabrics, the fine grained laminated sediments were vacuum-embedded in epoxy resin or Canada balsam, and thin sections were prepared. Thin layers of fine sand (1-2 mm thick) and medium silt $(0.5 \mathrm{~mm}$ thick) alternate in the fine sand-silt-sequence. The silty layers constitute confining beds; they are accentuated by iron oxide impregnations. Normal faults with little throw are observed in microscope (Fig. $3 \mathrm{~A}$ ). In some silt beds closely spaced changes in grain size at $100-200 \mu \mathrm{m}$ distances and more precipitation of carbonate stabilized the sediment. The little rounded (angular-subangular) quartz grains have been deposited with their long axes in the 

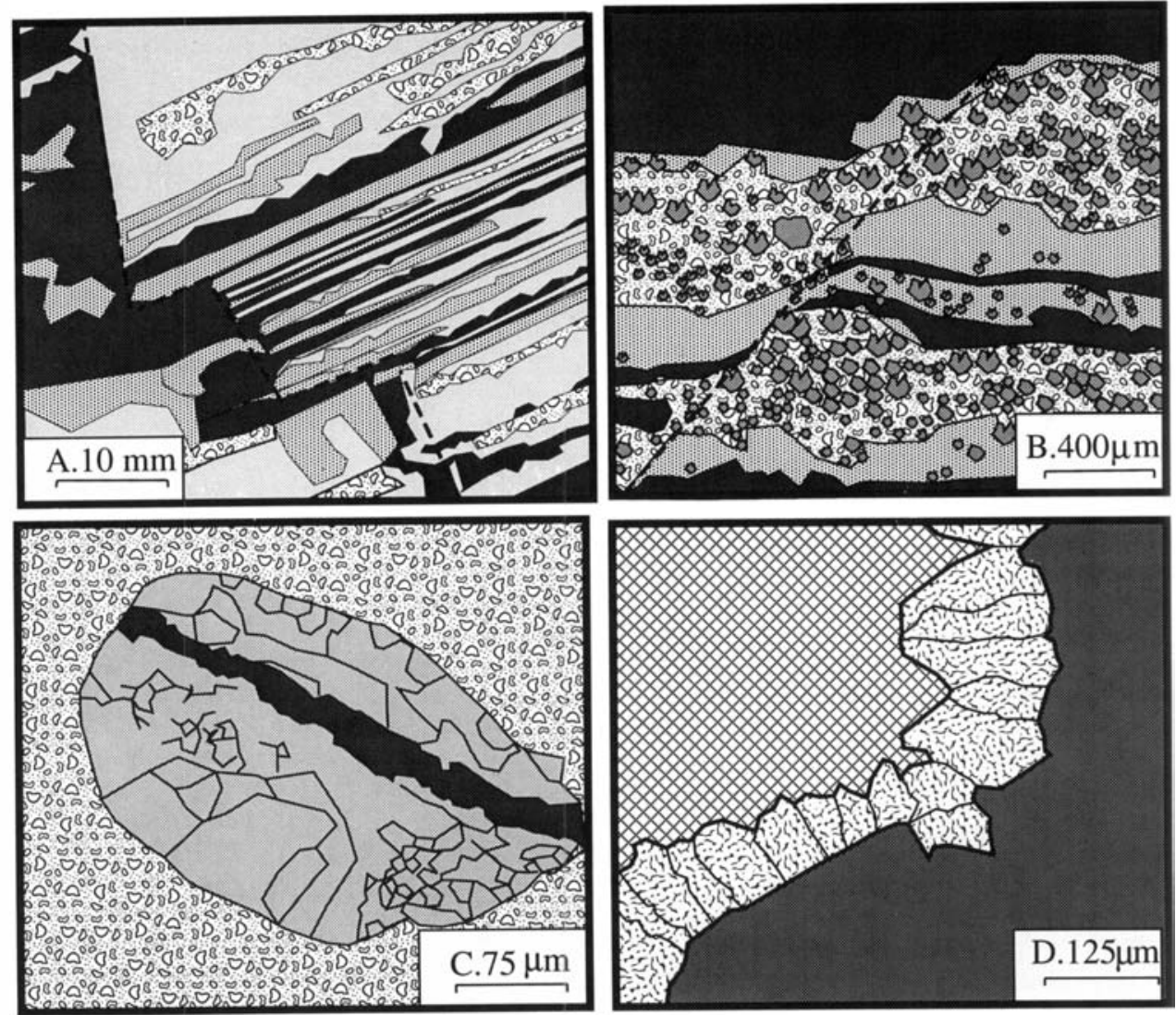

Fig. 3. Sedimentary fabrics in thin section.

A - laminated fine-sand-silt sequence with small dimensional echelon fault;

B - Micro normal fault within graded bedding of the fine sand-silt-sequence;

C - Section of an ostracode shell within the fossiliferous lacustrine lime sand;

D - Calcite rim cement arround a quartz grain of the fossiliferous lacustrine lime sand.

direction of flow. Quartz grains penetrate into the silt at interfaces. The silty beds have a lower content of carbonate; the quartz grains within these beds are partially encrusted by calcite. Repeatedly inversly graded bedding from clay to coarse silt or fine sand was found (Fig. 3B). Lateral changes in grainsize are attributed to gravitational redistribution due to originally vertical variation in density: Drope shaped (dense) silt sank into (less dense) clay. In addition, sand filled faults and mud cracks were observed.

The fine sand-silt-sequence was accumulated by continously alternating calm/stagnant and flowing waters, possibly with occasional drying due to exposure. Sand-filled faults indicate that thawing of dead ice started during sedimentation. Compared to the laminated, intensively faulted and almost nonfossiliferous fine sand-silt-sequence, the overlying lacustrine lime sand contains up to $90 \%$ calcium carbonate and many fossils. Within this sediment, grain sizes change from fine sand to silt at greater distances, i.e. at 1 to $5 \mathrm{~mm}$. The silty beds consist of a carbonate matrix with isolated quartz grains of $50-100 \mu \mathrm{m}$. Between the isolated clastic grains there is a micritic matrix of 5-10 mm sized calcite crystals without visible pore spaces. The quartz grains are surrounded by 
cement rims of calcite crystals (Fig. 3D). Moreover, some fossils were recognized in the microscop such as stalks and gyronites of charophytes, ostracode and pelecypode shells; within the homogenized portion also cross sections of gastropode shells were observed (Fig. 3C).

Quartz is the dominant clastic grain within the fine grained laminated layers. The larger quartz grains $(0.15-0.3 \mathrm{~mm})$ are subrounded and the smaller ones $(0.05-0.06 \mathrm{~mm})$ are angular. In addition, the clastic fraction contains plagioclases recognized by their twin-lamellae, some brown lamellar biotite aggregates, and $0.1 \mathrm{~mm}$ sized green glauconite aggregates. Sporadically fragments of quarzites and gneisses occur. Non-clastic minerals present are calcite (as cement and matrix) and iron oxide (as impregnation between the quartz grains).

The lacustrine lime sands are partially overlain by aeolian sands without carbonate composed of more or less equigranular quartz grains without cement.

\section{Grain sizes analysis}

\subsection{Aims, materials and methods}

The grain size analysis was carried out to established more subtle differences between various sediments on a former shore of a periglacial water. For that purpose the types of sediments encountered, i.e. glacifluviolimnic basin sands, fine sand-silt-sequences, lacustrine lime sand, soil horizons, colluvium and till, were sampled from $10 \times 10 \mathrm{~cm}$ sized squares. The coarse fraction $(0.063-10 \mathrm{~mm})$ were sieved wet, while the silt fraction was subjected to pipette analyses. The data are presented in log distribution curves; comparison is facilitated by calculation of mean, sorting $(\delta)$, skewness $\left(\alpha_{3}\right)$ and curtosis $\left(\alpha_{4}\right)$ after MARSAL (1967) and FRIEDMANN (1962).

Table 1 The range of moment measures within the various sediments.

\begin{tabular}{lllll}
\hline Sediment type & Mean [mm] & Sorting & Skewness & Curtosis \\
\hline $\begin{array}{l}\text { (upper) } \\
\text { basin sand 1 }\end{array}$ & $0.15-0.5$ & $0.77-2.3$ & $-2.61-0.34$ & $1.6-12.8$ \\
$\begin{array}{l}\text { (subjacent) } \\
\text { basin sand 2 }\end{array}$ & $0.11-0.23$ & $0.61-0.82$ & $-0.42-0.86$ & $3.71-5.0$ \\
$\begin{array}{l}\text { fine sand- } \\
\text { silt-sequence }\end{array}$ & $0.072-0.22$ & $0.79-1.2$ & $-1.6-$ & $2.27-5.4$ \\
$\begin{array}{l}\text { lacustrine } \\
\text { lime sand }\end{array}$ & $0.052-0.12$ & $0.7-1.4$ & $\begin{array}{l}-0.11) \\
-2.56-\end{array}$ & $1.65-9.9$ \\
soil horizons & $0.067-0.18$ & $0.9-1.55$ & $\begin{array}{l}-0.19) \\
-1.77-0.15\end{array}$ & $1.68-3.41$ \\
colluvium & $0.14-0.18$ & $1.16-1.38$ & $-0.79-$ & $3.24-4.28$ \\
& & & $(-0.23)$ & \\
\hline
\end{tabular}

\subsection{Description of the moment measures of the entire sedimentary complex}

The results of wet sieving of 60 untreated samples provide a general idea. The basin sediments, mostly laminated, are characterized by a bi- or polymodal grain size distribution. For glacifluviolimnic basin sands the maxima are in the fine sand and coarse sand or fine gravel, while for lacustrine lime sand they are in the coarse silt and medium silt ranges (Fig.4).

The relatively coarse grained basin sands are medium to poorly sorted (basin sand 1). Their skewness is mostly negativ and the curtosis reaches high values (leptocurtic) (Table 1). The high 

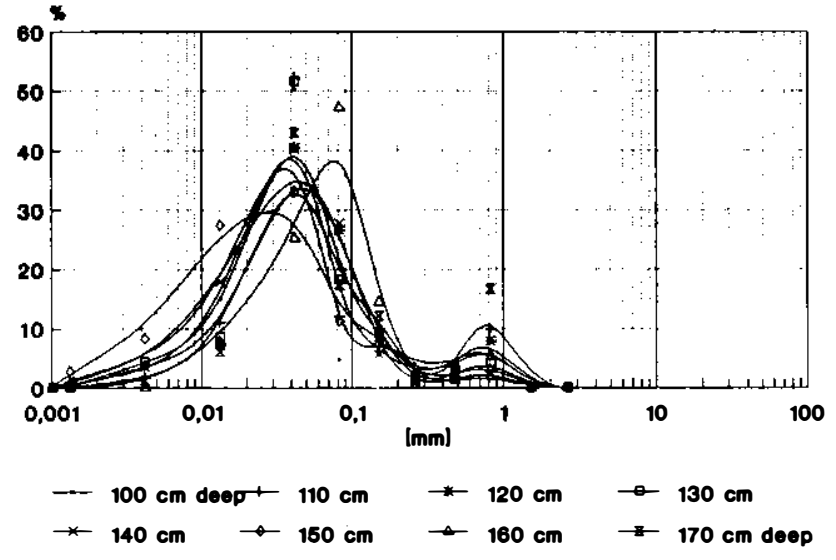

fine sand-silt-sequence (( 0,063-20 mm)
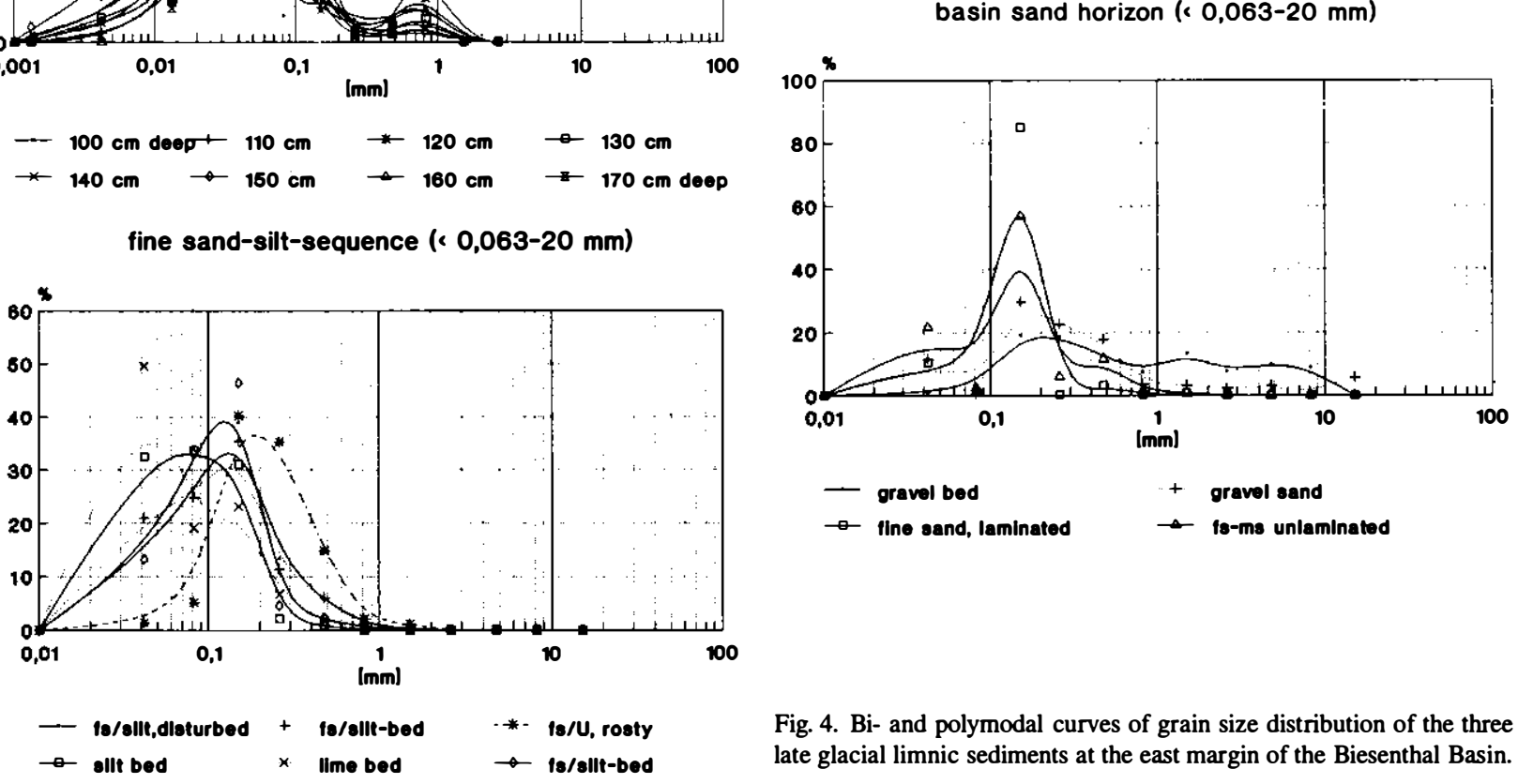

DOI:10.1127/zfgsuppl/99/1995/75 

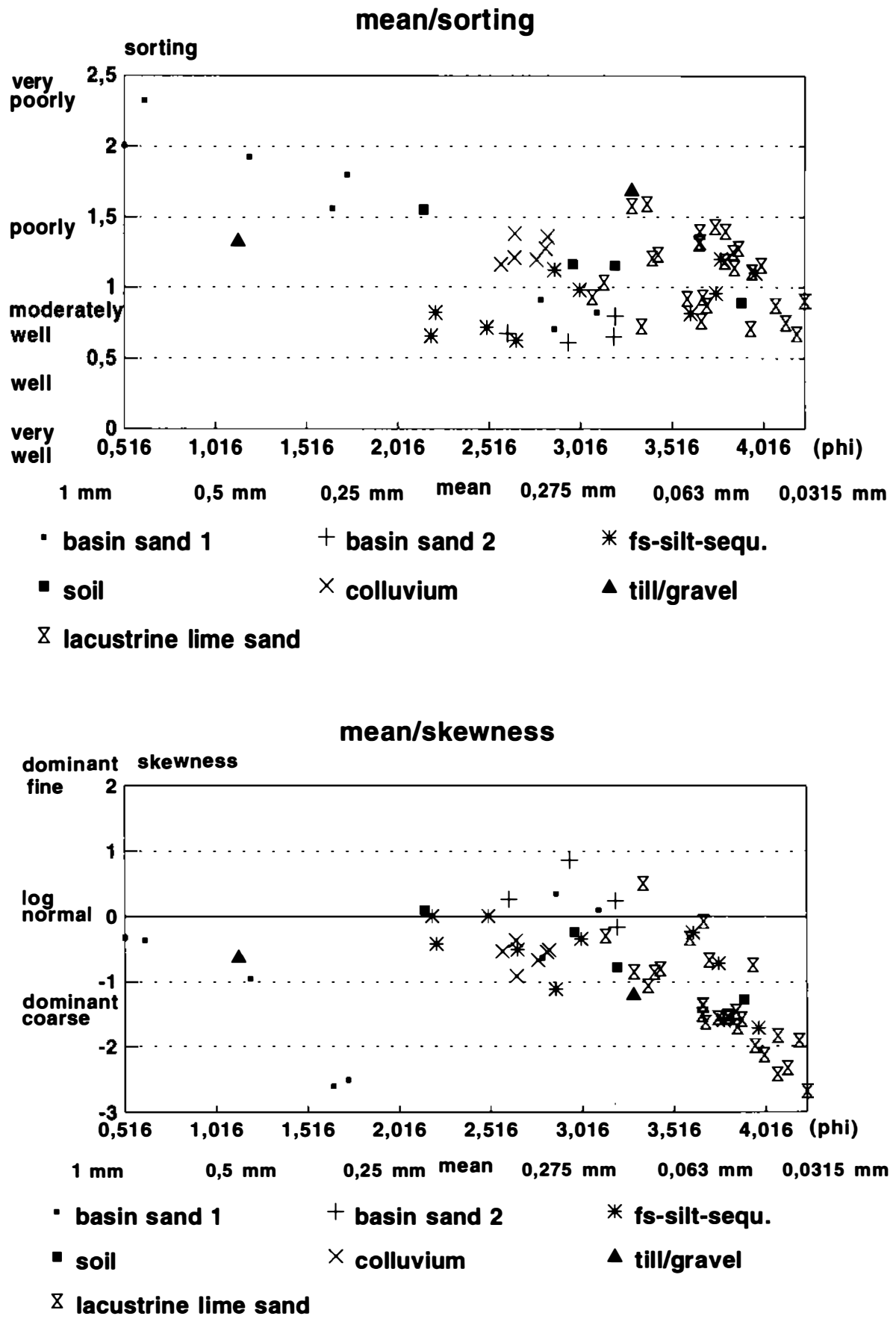

Fig. 5. Grouping of the sediments and course of the sedimentation process at the margin of a late glacial dead ice basin shown by means of the moment measures: mean, sorting and skewness. 
curtosis is related to the polymodal distribution and indicates the large variation in sedimentary conditions. As basin gradually get filled, the basin sands are more fine grained and better sorted (basin sand 2); skewness and curtosis do not vary so much (Table 1). This trend is continued in the overlying highly deformed sequence of fine sands and silts, which is medium sorted fine sand; its skewness is always negativ reflecting dominant coarse grains. The curtosis is at the transition from platycurtic to leptocurtic, indicating stable to slightly varying sedimentary conditions (Table 1).

Above following lacustrine lime sand are medium sorted fine sands to coarse silts. Their negative skewness moment expresses an asymmetry toward the coarser fraction, which is interpreted either as higher level to transport energy (v. ENGELHARDT (1973) or changing energy levels (DUANE 1964). The latter interpretation is supported by the wide ranges of the curtosis. As moment measures mean and sorting are plotted according to FRIEDMANN (1961), groupings as well as succesions are apparent (Fig. 5). The basin sands trend from coarse grained/poorly sorted to fine grained/well sorted sediments. In contrast the fine sand-silt-sequence moves from coarse grained/ well sorted up to fine grainde/poorly sorted; similarly the lacustrine lime sands trend toward fine grained/poorly sorted sediments. The colluvium samples mark a narrow range because of constant depositional conditions.

The general pattern is even more clearly evident in the plot of skewness and mean (Fig. 5). The mean portion is composed of fine grained sediments, which with decreasing grain size contain a higher proportion of their coarse fraction. Also evident is the gradual transition from the fine sand-silt-sequence to the lacustrine lime sands.

In summary, in the course of filling the periglacial basin grain sizes tend to become finer and sorting to become better. However, discontinuous thawing of subjacent dead ice leads to variations in sedimentational processes and fluctuation of sediment properties.

\section{$4 \quad$ Quartz grain surfaces \\ 4.1 Method of investigation}

The assessment of the quartz grain surfaces is limited on one profile consisting of three clearly discernible types of sediment:

- a laminated glacilimnic basin sand as subjacent horizon;

- a laminated fossiliferous lacustrine lime sand;

- an aeolian sand at the top.

From each sediment type, the roundness of 700-900 grains of the fraction $0.3-1 \mathrm{~mm}$ was assessed as follows:

1) well rounded (rounded to well rounded; after SHEPARD 1963);

2) subrounded (subangular to subrounded);

3) angular (very angular to angular).

Further in each group dull and shiny grains were distinguished (Photo 1).

Well rounded grains exhibit low surface relief and a circular to oval outline. Subrounded grains bear a clearly descernible relief but largely rounded edges, while angular grains bear a pronounced relief, frequently straight edges which may partly rounded. Often sharp-edged outlines occur. Flat grains were also asigned into this group.

10-20 grains were selected from each of these 6 groups and each of these sediment types (total 260 grains). They were prepared using the method of GrOMOLL (1990):

- 5 min boiling in 10 percent $\mathrm{HCl}$;

- 2 min ultrasonic treatment;

- 5 min boiling in ethanol;

- each time washing with aqua dest;

- preparation for SEM. 

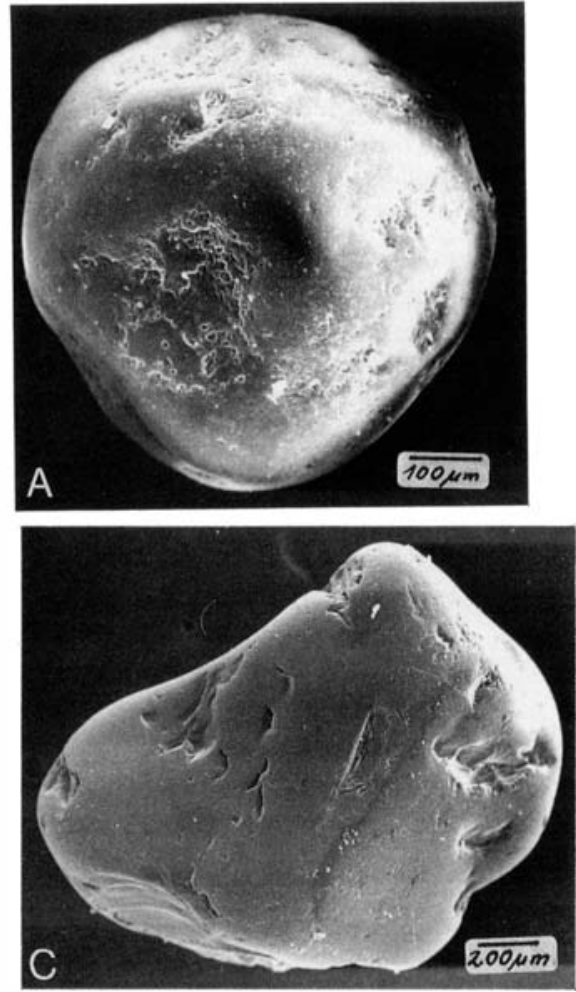
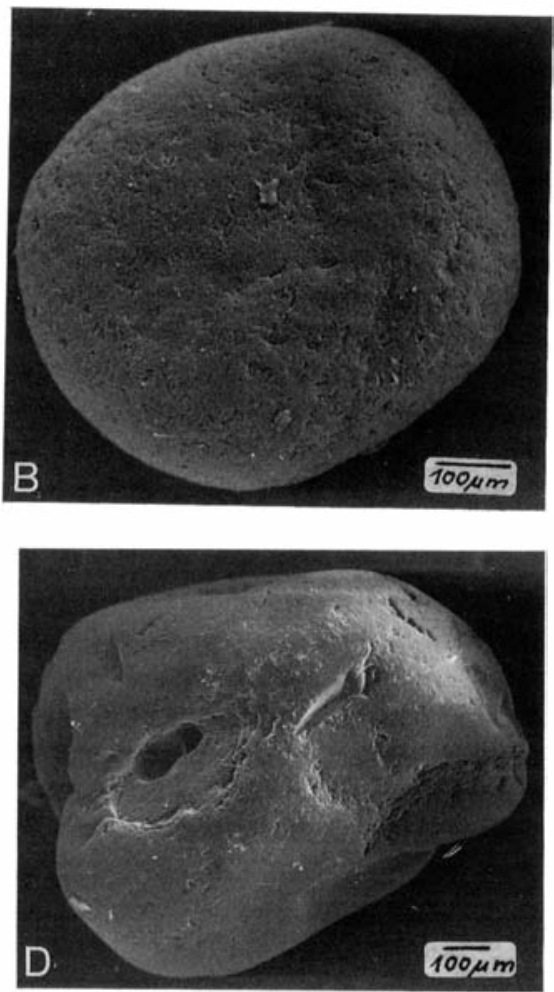
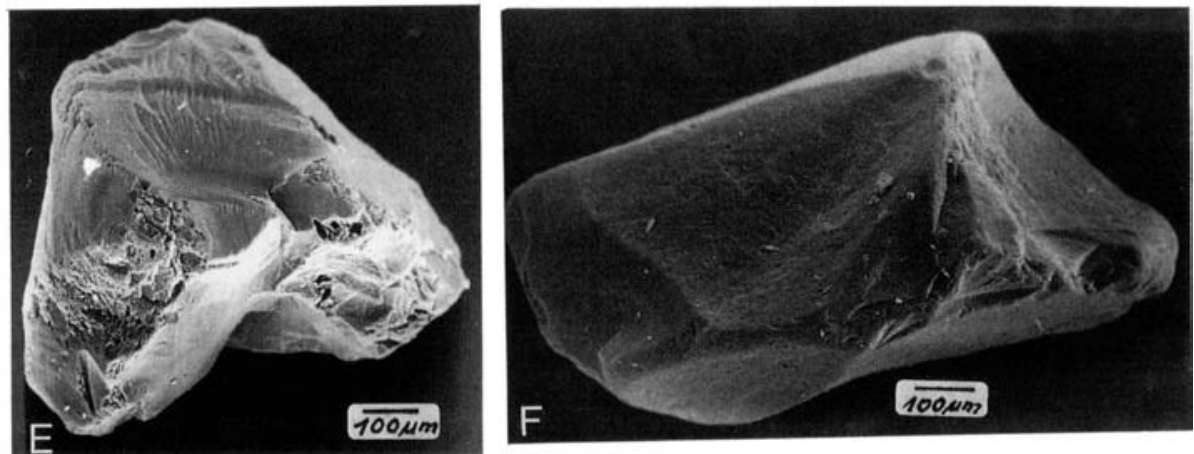

Photo 1. Quartz grains of the glacilimnic basin sands as examples of the grain, groups distinguished: well rounded shiny (A), well rounded dull (B), subrounded shiny (C), subrounded dull (D), angular shiny (E), angular dull (F).

This investigation intended to apply the method developed by KRINSLEY \& DOORNKAMP (1973) to these sediments from known sedimentary, environments of the Late Weichselian in Brandenburg, and to test the diagnostic potential of the criteria advanced by KRINSLEY \& MARGOLIS (1971). They can be used as indicator where other methods failed or provided ambiguous results. 


\subsection{Presentation of the observed textures}

For observation surface feature were selected which are related to genesis or later reworking of the material, i.e. glacial, subaquatic and aeolian features (according to KRINSLEY \& DOORNKAMP 1973).

The glacial environment is characterized by the destruction of the grain surfaces due to outbreaking of grain fragments. In that way a very high relief has been formed with stepped fractures, parallel grooves and groove-striped surfaces.

The subaquatic environment includes all environments in which sand grains were transported, worn and accumulated by water. The grains studied were subjected to fluvial and limnic (low energy litoral) conditions. V-shaped and linear or curved grooves are atributed to the collision of quartz grains in moving water. The wave agitation within the environment and the flow of river water led to repeated reqorking of the sediment; in this process the grain surfaces spalled or were scratched.

Aeolian transport and wear of the quartz grain surfaces lead to rounding of the edges and corners. Small and flat bowle-shaped depressions characterize the surfaces. Moreover a finely porous surfaces texture causing the dullness of the grains seems to be typically. These textures are due to frequent grain-grain-collision during the aeolian transport. Larger structures may be formed by grain-bottom-collision.

\subsection{Results of grain surface studies}

Comparing of proportions of the six groups within the three sediment types (Fig. 6), clearly in the aeolian sand the proportion of dull grains is highest, as would be expected. The glacilimnic basin sands show the highest share in angular shiny grains, which were affected by the least wear. The lacustrine lime sand occupy an intermediate position in every respect: The share in subrounded grains is lager than in the other sediments and the share in well rounded grains is lowest. A relative large percentage of grains show dull surfaces.

Glacial wear determined the shape of the angular quartz grains of the glacilimnic basin sands (Photo 2). The effect of large features decrerases with the degree of roundness. Nearly all glacial features are overprinted subaquatic by V-shaped indentation, deep pits and grooves. Only in protected positions of the surface sharp edges remain. The surfaces of the dull grains show a finely porous texture, which in rare cases is due to closely echeloned minute $(1 \mu \mathrm{m}) \mathrm{V}$-shaped indentation, but dominantly characterized by very small holes and the resulting rough surface which is supposedly caused by aeolian wear.

The importance of the glacial features is still more reduced within the lacustrine lime sand (Photo 3). All fracture edges are worn and overprinted by subaquatic V-shaped intendation and aeolian features. A succession of subaquatic and aeolian wear is recognized. V-shaped intendations occur in sizes of $1-2 \mu \mathrm{m}, 10-30 \mu \mathrm{m}$, and $100-300 \mu \mathrm{m}$. The well rounded dull grains show a stronger aeolian influence.

The traces of earlier wear are still visible on grains of the covering aeolian sand sheet (Photo 4), mainly in groups of the shiny and less rounded grains. In contrast, these traces are very strong suppressed at the dull grains. The glacially caused high relief has been largely flattened, but is still dicernible on subrounded grains. In addition to the small holes causing the fine-porous surface, sickle-shaped textures occur. They are similar to those artifically produced in the wind tunnel (KRINSLEY \& DOORNKAMP 1973). The porous texture is restricted to external/exposed surfaces of the grains; it never occurs in the inner portions of depressions protected from grain collisions.

Assessment of the quartz grain surfaces from the three sediment types studied yielded the following results: 

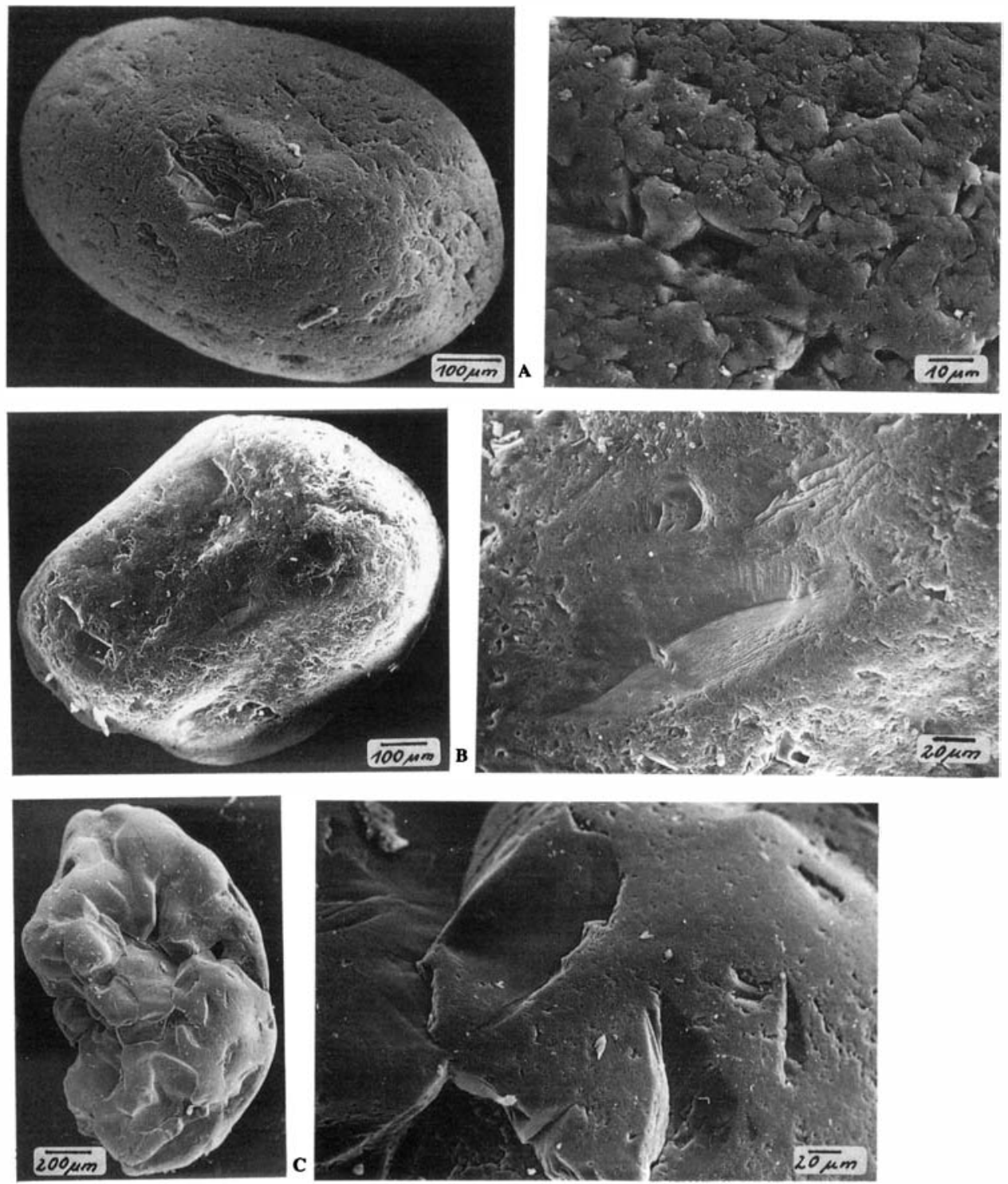

Photo 2. Quartz grain surfaces of the glacilimnic basin sand (entire grain and detail): subaquatic V-shapes indentation and grooves dominate (A, C); glacial traces are clearly visible (C); slight aeolian overprint (B).

1. The grains show structures of three size ranges, i.e. $100-300 \mu \mathrm{m}, 10-30 \mu \mathrm{m}$ and $1-3 \mu \mathrm{m}$; of these the largest ones determine the shapes and the smallest ones overprint those formed before.

2. Glacial textures are the largest and first (oldest) ones. The degree of their wear increases with roundness. 


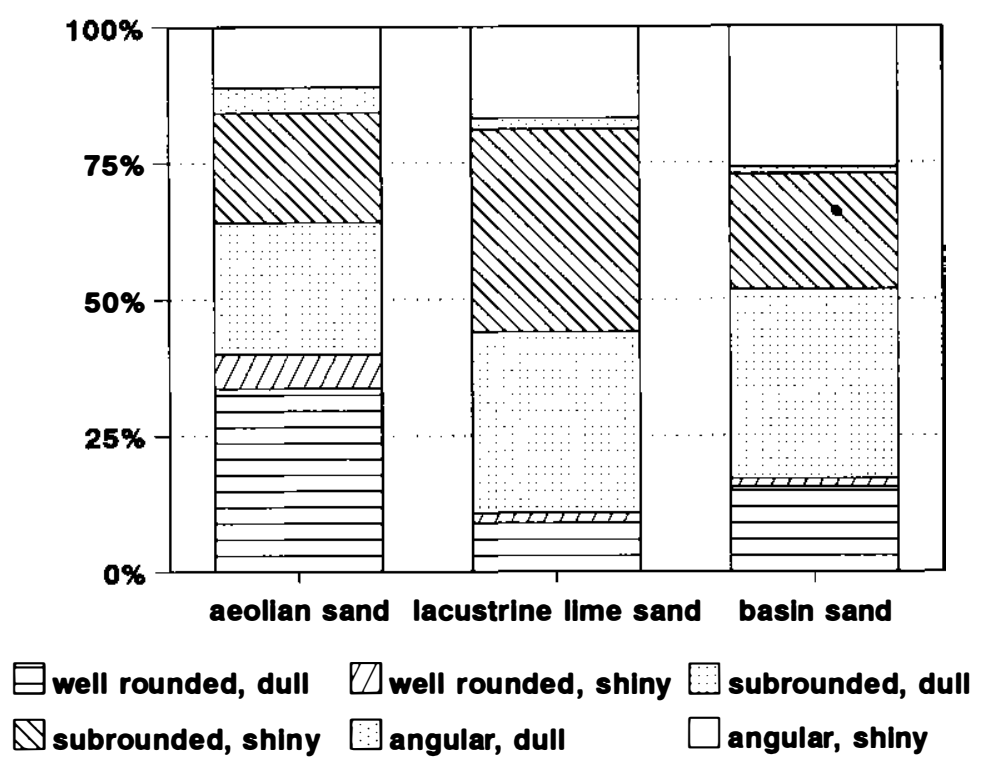

Fig. 6. Shapes and surface textures of quartz grains from the fraction $0.3-1 \mathrm{~mm}$ of the profile basin sand/ lacustrine lime sand/aeolian sand at the eastern margin of the Biesenthal Basin.

3. The shiny grains are characterized by clearer and often sharper textures than the dull ones.

4. The dull surfaces bear a finely porous textures, which is almost identical on all grains.

5. With respect to sediment type the dominant textures are:

- in basin sands: glacial and subaquatic;

- in lacustrine lime sands: subaquatic and aeolian;

- in aeolian sands: aeolian.

6. In all sediment types aeolian wear was found on some grains; they indicate aeolian admixture to basin sediments.

\section{$5 \quad$ Final considerations}

The succession of glacial, subaquatic and aeolian wear confirms the ideas of basin genesis in the area of study (NITZ et al. 1994). In the course of filling dead ice basins sedimentary processes varied, specifically the energy of transport varied continously. Sedimentation accompanies the thawing of dead ice, which apparently did not proceed continously and included phases of drying up. The aeolian component is of considerable importance during sedimentation and is detected in all basin sediment types. In the late glacial lime rich near-surface sediments diagenetic processes such as cementation take place. Macrofabrics often are mirrored in microfabric (normal faults, graded bedding, gravitational deformation). Thus fabric and texture-forming processes concur parallel at various levels of dimension or else are cumulativ effects of micro-processes. 

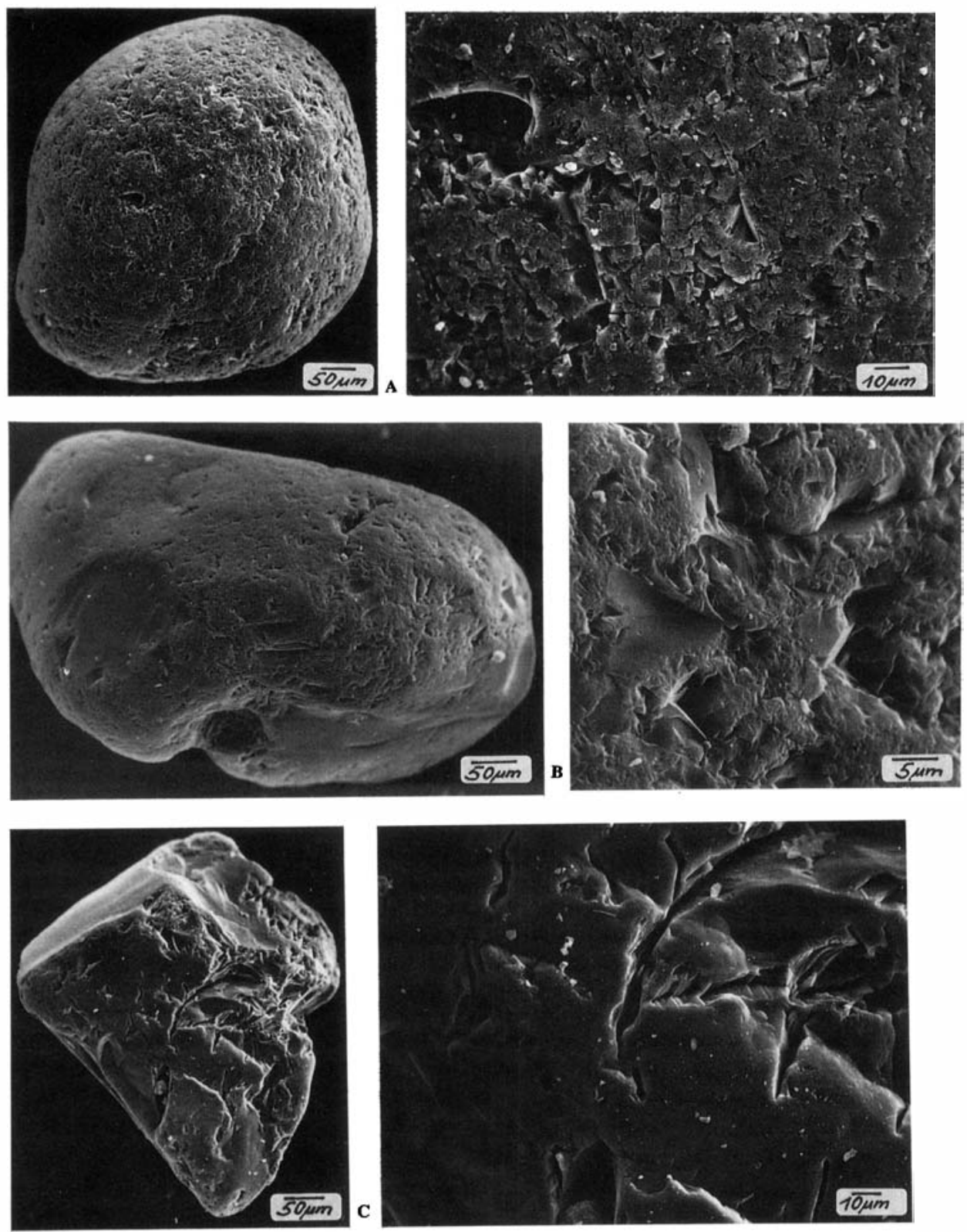

Photo 3. Quartz grain surfaces of the lacustrine lime sand (entire grain and detail): subaquatic V-shapes indentations and grooves dominate (A, C); glacial textures are less important (C); finely porous aeolian overprint is visible (A). 

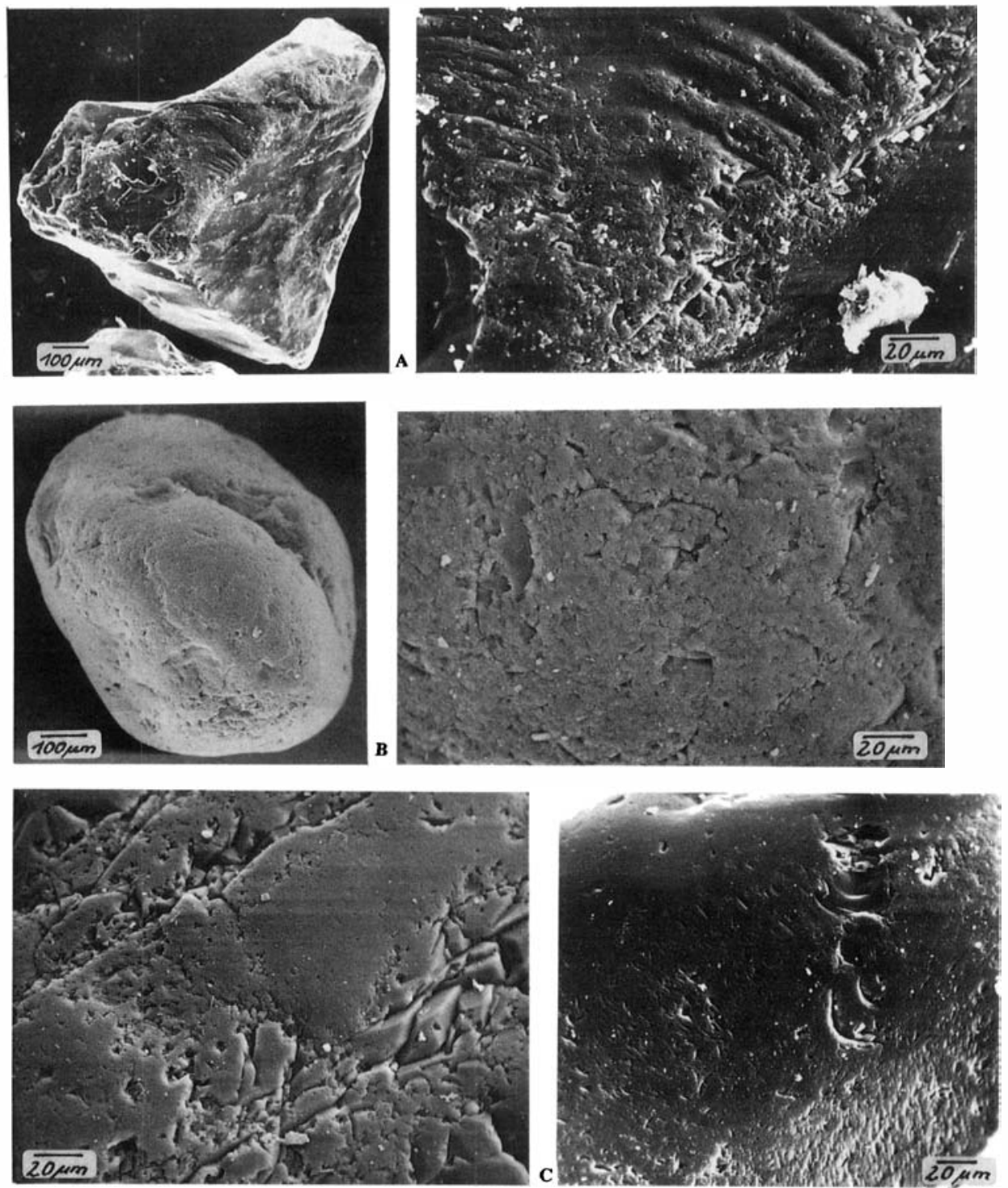

Photo 4. Quartz grain surface of the aeolian sand (entire grain and detail): glacial textures are visible but overprinted (A); subaquatic textures are clearly visible (C); in the case of dull grains all traces of earlier wear are suppressed (B). 


\section{References}

СнRовок, S. M. \& B. NITZ (1987): Die Entwicklung des Gewässernetzes der Oberen Finow vom BlankenbergInterstadial bis heute. - Wiss. Z. Enst-Moritz-Andt-Univ. Greifswald, Math.-nat. wiss. Reihe 36 (2-3): 20 -25 ; Greifswald.

- - (1989): Ergebnisse physisch-geographischer Prozeßforschung im Biesenthaler Becken: Sedimentationsabläufe vom Spätglazial bis Holozän. - Z. geol. Wiss. 17 (1): 77-84; Berlin.

DuANE, D. B. (1964): Significance of skewness in recent sediments, Western pamlico sound, North Carolina. J. Sed. Ped. 34 (4): 764-874; Tulsa/Okl.

EngelHARDT, W. v. (1973): Die Bildung von Sedimenten und Sedimentgesteinen. Sedimentpetrologie, Teil III. 378 pp.; Stuttgart (Schweizerbart).

FRIEDMANN, G. M. (1961): Distinction between dune, beach, and river sands from their textural characteristics. J. Sed. Ped. 31 (4): 514-529; Tulsa/Okl.

- (1962): On sorting, sorting coefficient and lognormality of the grain-size distribution of sandstones. J. sed. Petrol. 70: 737-753; Chicago.

GROMOLL, L. (1990): Quarzkornoberflächenuntersuchungen an Sedimenten der südwestlichen Ostsee - Ein qualitativer und halbquantitativer Vergleich. - Z. geol. Wiss. 18 (7): 615-635; Berlin.

KRINSLEY, D. H. \& J. C. DOORNKAMP (1973): Atlas of quartz sand surface textures. - 91 pp.; London (Cambridge Univ. Press).

KrINSLey, D. H. \& S. V. MARgolis (1971): Grain surfacetexture. - In: CARVer, R. E.: Procedures in sedimentary petrology. - 151-180; New York (Wiley).

MARSAL, D. (1967): Statistische Methoden für Erdwissenschaftler. - 152 S.; Stuttgart (Schweizerbart).

NITZ, B. (1984): Grundzüge der Beckenentwicklung im mitteleuropäischen Tiefland - Modell einer Sedimentund Relief genese. - Petermanns Geographische Mitt. 128 (2): 133-142; Geotha.

NITZ, B., L. SCHIRRMEISTER \& R. KLESSEN (1994): Spätglazial-altholozäne Landschaftsgeschichte auf dem nördlichen Barnim - Komplettierung eines Modells der Beckenentwicklung im nordostdeutschen Tiefland. Petermanns Geogr. Mitt. (im Manuskript vorliegend); Gotha.

SHEPARD, F. P. (1963): Submarine Geology. - 557 p.; New York, Evanston, London (Harpers \& Row).

Address of the author: Dr. LUTZ SCHIRRMEISTER, Humboldt-Universität zu Berlin, Fachbereich Geographie, Chausseestraße 86, D-10099 Berlin. 